\title{
A ordem carnavalesca
}

\author{
MARIA ISAURA PEREIRA DE QUEIROZ
}

RESUMO: A autora estuda as manifestações carnavalescas nas cidades de Tatuí, Piracicaba e São João del Rei. Baseando-se nas observações das formas pelas quais o Carnaval é celebrado nos bailes e nas ruas, questionam-se as interpretações que concebem o Carnaval como um lugar aonde as normas às quais os cidadãos se adaptam cotidianamente parecem abolidas. Pelo contrário, a pesquisa mostra que a estrutura social permanece durante estas festas, o que pode ser notado pela separação entre espectadores e foliões nas ruas, e na presença dos diferentes grupos sociais, cada um em seu respectivo bloco carnavalesco. Estes fatos apontam que as origens sócio-econômicas das pessoas se mantém e se reproduzem durante o Carnaval.

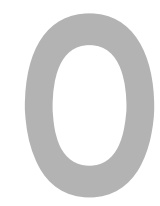

s diversos autores que estudam o Carnaval, no Brasil e fora dele, o definem em geral como um período em que, numa sociedade dada, uma mesma emoção e alegria se apodera de todos os indivíduos, apagando as diferenças sócio-econômicas e étnicas vigentes no cotidiano. O conjunto de normas com as quais os cidadãos se conformam habitualmente nos seus comportamentos parecem abolidas, ou teriam estes decidido desobedecer a elas. A ordem social comum deixaria de existir: as idades se misturam, as cores da pele deixam de dividir; homens se vestem de mulher e mulheres de homem; as classes sociais não são mais discerníveis.

Instalar-se-ia a desordem durante esse período; constata-se agora um estado de fato, sem ser possível captar relações definidas pelas leis sociais corriqueiras e há quem manifeste a opinião de que tal festa poderia até mesmo constituir um prelúdio de transformações sociais. Ou então fala-se de loucura coletiva, de um delírio tomando conta de todos os

UNITERIMOS:

Carnaval, ordem, estrutura social, cotidiano.

Professora do Departamento de Sociologia da FFLCH-USP 
1. O Carnaval do Rio de Janeiro foi recentemente estudado pela autora (1992) em Carnaval brasileiro: o vivido e o mito, também publicado em francês sob o título Carnaval brésilien: le vécu et le mythe.

2. Tatuí é cidade de mais ou menos 45.000 habitantes, que se orgulha por possuir afamada Escola de Música. São João del Rey, de 54.000 habitantes, foi importante no séc. XVIII devido às minas de ouro; hoje conhece uma revivescência graças a minas de cassiterita e manganês. Piracicaba, com 180.000 habitantes, tem indústrias metalúrgicas e siderúrgicas, mas também se destaca pela agricultura e pelas importantes usinas de açúcar. cidadãos, que subverte a estrutura social numa atmosfera de descontração e de alegria.

No entanto, em estudo recentemente publicado ${ }^{1}$, efetuado no Rio de Janeiro, cidade considerada no Brasil e no exterior como a cidade carnavalesca por excelência, algo de diferente foi observado: a alegria e a excitação não se espalhavam por toda a parte na cidade, e além disso, as escolas de samba, no seu desfile rigorosamente organizado que compõe o símbolo mesmo da festa de Momo, seguem uma "obediência estrita à ordem", indispensável para que o cortejo se desenrole com toda a sua magnificência (Pereira de Queiroz, 1992, p. 116). Também não é o povo que contempla o grande espetáculo, e sim somente aqueles que podem arcar com a despesa de um lugar nas arquibancadas, cujos preços não são dos menores. Poder-se-á perguntar: e nas pequenas e médias cidades deste país, nas quais os indivíduos muito mais facilmente se conhecem uns aos outros, em que abundam os grupos primários com suas relações face a face, não tomaria o Carnaval uma outra forma, diversa da que é encontrada nas megalópoles onde as relações tendem a ser impessoais?

Para este estudo foram escolhidas, citadas como muito carnavalescas cidades de médio e pequeno porte como Piracicaba, em região industrializada do Estado de São Paulo, que se destaca pelo seu aspecto abastado e moderno, São João del Rei, que se integra entre as famosas Cidades Históricas do interior de Minas Gerais, com suas igrejas barrocas e casas do séc. XVIII; Tatuí pequena cidade tranqüila no interior de São Paulo, cuja economia se baseia ainda na agricultura, e que se distinguiria entre as outras por conservar resquícios de folclore ${ }^{2}$. Um traço é peculiar a São João del Rei, que as outras não apresentam: berço de famílias antigas, as quais, mesmo quando não habitam mais ali, conservam uma acirrada afeição e a ela retornam com freqüência pelo menos para passar as férias, o que não se verifica nas outras duas.

Nestas três cidades, o tríduo carnavalesco é festejado em cortejos desfilando pelas ruas centrais, assim como em bailes fechados. Os folguedos de rua também não tem lugar por toda a parte, mas se realizam em determinadas ruas, praças, avenidas, apresentando pois o seu locus particular, ficando as demais sempre calmas e silenciosas; mas a animação nas que constituem o palco dos desfiles também só dura enquanto estes estão ali dançando, para em seguida recobrar a sua quietude. Dessa maneira, existe um local e um tempo carnavalescos; aqueles indivíduos que, fora do lugar e do momento, manifestarem a alegria do reinado de Momo, dançando e cantando, são alvo de risota e motejos.

Os bailes carnavalescos, realizados sempre em clubes, estão abertos aos sócios ou a pessoas convidadas por estes; as entradas são pagas, mesmo a dos sócios, e a dos convidados são naturalmente mais caras. Os clubes realizam à noite bailes para os adultos, não admitindo, em geral, menores de 18 anos. Porém à tarde existem sempre bailes chamados "in- 
fantis", em que adolescentes se entregam à dança e ao canto, juntamente com as crianças. Na menor das três cidades, Tatuí, é encontrado menos rigor na separação etária dos bailes noturnos, onde se divertem jovens de ambos os sexos, a partir de 14 anos de idade. No entanto, a separação econômica é rigorosa nas três cidades: os mais abastados freqüentam os clubes da alta, há clubes mais modestos e até mesmo clubes considerados de operários, em geral associados a pequenos times de futebol. Seria impensável que as pessoas de mais posses da cidade fossem aos bailes destes dois últimos clubes, a não ser por curiosidade, para se divertirem com a falta de jeito dos matutos. Assim, nas cidades médias e pequenas, as classes sociais permanecem perfeitamente estanques durante os bailes carnavalescos, como já se havia observado no Rio de Janeiro (Pereira de Queiroz, 1992, p. 119-155).

É comum pensar, no entanto, que estas divisões desaparecem totalmente no chamado Carnaval de rua, em que, como se supõe, a multidão desconheceria todas as separações sócio-econômicas, étnicas, de idade, de sexo. Nas três cidades estudadas, os desfiles carnavalescos, que compõem o Carnaval de rua, se realizam sempre à noite, dele participando gente de todas as idades, a partir de crianças às vezes bem pequenas, pois não raro um pai traz nos ombros ou ao colo um pequeno carnavalesco devidamente fantasiado mas que ainda não anda. No entanto, há uma nítida divisão espacial: aos foliões (isto é, os componentes dos cortejos) está reservado o leito das ruas, enquanto aos espectadores cabem as calçadas. Nota-se aqui uma primeira divisão muito nítida entre os participantes da festa: atores e espectadores.

A linha que os divide pode ser tênue, isto é, apenas separando quem fica na calçada admirando, e quem está na meio da rua, foliando. Nas duas cidades maiores, porém, a divisão se exprime de maneira contundente, por meio de arquibancadas que são construídas especialmente para os festejos; além disso, elas se apresentam de maneira a não permitir que olhares não-pagantes possam ver, pelos seus vãos, parcelas do espetáculo, que fica assim destinado apenas a espectadores dotados de posses; o povaréu somente pode ver os cortejos antes de sua entrada, quando ainda não se formaram, ou então à saída, quando estão se desmembrando, não gozando da visão de conjunto com seu movimento e seu colorido. Numa cidade pequena como Tatuí quem chegar primeiro à beira das calçadas ocupa os melhores lugares; os mais afortunados procuram reservá-los, colocando ali bancos e cadeiras, ocupadas pelos serviçais da casa e pelas crianças desde o início da tarde, para que os adultos e os mais velhos possam comodamente usufruir da festa desde seu início, por volta das 19 horas.

Nas três cidades, o Carnaval de rua é sempre um desfile de grupos fantasiados, patrocinado pela prefeitura local, que dá comumente o seu aval, assegura o policiamento, podendo ou não oferecer também uma subvenção. Como em bailes carnavalescos, nas ruas a ocorrência dos gru- 
3. Câmara Cascudo se detém principalmente na descrição dos blocos (ver 1962, $1^{\circ}$ vol., p. 115 e $240 ; 2^{\circ}$ vol., p. 648-649).

4. Vertambém Von Simson, 1984; Rodrigues, 1984; Von Simson, 1989. pos fantasiados é habitual pelo Brasil todo, e o renomado folclorista Câmara Cascudo assim os descreve em seu livros chamando-os de blocos ${ }^{3}$ : indumentária uniforme, hino-marcha composto para o folguedo, um conjunto de percussão que executa a música sem cessar, algumas vezes um estandarte; constituindo forma antiga de participação, tais conjuntos eram em geral improvisados entre amigos e vizinhos às vésperas dos festejos de Momo.

Hoje em dia, porém, cresceram em importância, procurando não se chamar blocos, cordões ou ranchos, como em tempos antigos; copiando o que existe no Rio de Janeiro desde 1928, aqueles que se organizam com antecedência e buscam ostentar certa riqueza em suas fantasias, fazem-se chamar escolas de samba, copiando no nome e também na maneira de desfilar os reputados modelos cariocas como Mangueira, Portela, Beijaflor, etc. Tatuí, a cidade mais pobre das três, tem somente duas escolas de samba, completadas por dois blocos e um cordão. São João del Rei tem vários blocos, ranchos e cordões, além de uma famosa escola de samba. Piracicaba, finalmente, apresenta várias escolas de samba grandes e ricas, e também faz vir da cidade de São Paulo algumas das que nesta existem, e que mediante o pagamento de emolumentos, vem ali se exibir na $2^{\mathrm{a}}$ feira de Carnaval, dia "fraco" em que não desfilam as grandes escolas.

Como no caso dos bailes carnavalescos, observa-se nas três cidades a manutenção das hierarquias sócio-econômicas durante os folguedos carnavalescos, o que já havia sido constatado em estudos anteriores (Pereira de Queiroz, 1992) $)^{4}$ nos espaços urbanos destinados à festa, os locais ocupados pelas diversas camadas sociais são sempre bem delimitados. A separação é menos evidente numa cidade menor, como Tatuí, atingindo seu ponto mais elevado nas duas outras cidades em que são construídas arquibancadas. $\mathrm{O}$ tamanho da cidade, resultante de sua maior ou menor riqueza econômica, assim como da maior ou menor riqueza da zona em que se encontra implantada, dá lugar a uma população urbana muito mais diferenciada quanto às posições sociais e às atividades econômicas, o que se reflete diretamente na ordem do carnaval de rua. Nas três cidades, a festa ao ar livre não se apresenta como uma invasão das ruas por multidão sedenta de dançar e cantar, e sim como uma festa bem organizada, em que a ordem imperante é a ordem sócio-econômica local e habitual.

Além disso, em nenhuma das cidades, nem mesmo na modesta Tatuí, a chamada loucura momesca toma conta da totalidade urbana. Não só existe um espaço bem delimitado onde ocorre a folia, como também uma parte importante da população nem mesmo participa dela como espectadora. Muitas famílias mais abastadas desdenham a festa, partem para suas propriedades rurais (quer sejam fazendas, quer sejam sítios), ou vão para a capital visitar parentes; as de menos posses aproveitam os feriados para descanso. $\mathrm{Na} 2^{\mathrm{a}}$ feira Gorda, nas três cidades observadas, a tendência é para comércio e funcionalismo público trabalharem pelo 
menos meio período. A demência coletiva não é tão disseminada quanto se pretende.

À divisão entre espectadores e atores, tão clara quando se observa o que ocorre nos locais de celebração da festa, acrescenta-se uma terceira, existente igualmente nas três cidades mencionadas. Além de espectadores e atores, tanto nos bailes quanto nos desfiles, existem aqueles que "estão de serviço". Agentes de polícia nas ruas e nos bailes cumprem sua função de assegurar a ordem. Também há sempre nos bailes um serviço de buffet, e, nos clubes mais ricos, um vestiário organizado. Nas ruas, é em determinadas esquinas, assim como em todos os largos e praças, barraquinhas de comestíveis, refrigerantes, bugigangas, oferecem sua mercadoria e vendedores ambulantes circulam em toda a parte. Todos eles, embora estejam no mesmo espaço que os foliões, não se misturam nem com os atores, nem com os espectadores. Seu papel é de grande importância, pois compõem uma infra-estrutura indispensável à realização dos folguedos; porém, embora mergulhados na atmosfera de entusiasmo e alegria, embora às vezes pintem seus rostos e enverguem chapéus de palhaço, estão na verdade ganhando sua vida: suas atividades são totalmente diversas da dos carnavalescos. Atores, espectadores, servidores, são as diferenciações de base do Reinado de Momo, onde há sempre os que agem, os que contemplam e os que servem. $\mathrm{O}$ espaço carnavalesco não se divide apenas entre os que olham e os que dançam; uma terceira divisão, menos clara porém existente, separa estas duas categorias da categoria dos que trabalham.

Desta maneira, no espaço e no tempo carnavalescos, os comportamentos dos que estão reunidos se diferenciam conforme os papéis que desempenham. Atores e espectadores podem estar unidos pela comunhão da festa; coexistem, como se vê, em espaço e tempo, com os servidores, que ali mesmo conservam as atividades de sua vida habitual. Em que medida se poderia dizer que estes também, a seu modo, gozariam da festa carnavalesca? Presos a sua labuta cotidiana, podem perfeitamente estar fora da aura de emoção, mesmo quando arboram na vestimenta algo que os liga aos foliões. Quanto ao entusiasmo de atores e espectadores, o teor é também diverso; alguns espectadores podem dançar e cantar enquanto vêem passar os cortejos, porém nas três cidades estudadas, a maioria se comporta como público, como aqueles que assistem a um espetáculo. Assim, no espaço e no tempo carnavalescos, a conduta dos que festejam é diversa em qualidade e grau. $\mathrm{O}$ folião que desfila transporta consigo a carga mais intensa da febre carnavalesca; os espectadores a apresentam em grau muito menor: e os servidores, presos a uma labuta que é idêntica à do cotidiano, estão fora da aura da emoção. Em que medida, ao observar o Carnaval de rua, poder-se-á afirmar que se trata de uma loucura carnavalesca coletiva?

Esta descrição das festas carnavalescas em três cidades diferentes do interior do Brasil vem corroborar afirmações já anteriormente 
efetuadas sobre a grande semelhança delas por toda a malha urbana nacional. Dessemelhantes em tamanho e nas atividades econômicas que lhes são fundamentais, todas elas lançam mão das mesmas formas de folguedo, que são os bailes e os desfiles de rua. No entanto esta parecença, embora básica, não apanha a totalidade do fenômeno em cada uma delas e, o que é mais importante, quando, como espectadores, se participa da realização de cada uma, a primeira visão é a grande dessemelhança entre elas. As igualdades enumeradas atrás constituem um resultado da análise dos fatos observados, não do que se captou pela observação direta e participante.

Das três cidades, São João del Rei se apresenta como a de maior intensidade carnavalesca. No sábado gordo, às 5 horas. da madrugada, começa a folgança com o Bloco da Alvorada: Um grupo de foliões de pijama ou de camisolas de dormir, saracoteia animado até que o sol já esteja forte, ao som de uma charanga tocando velhas marchinhas e sambas; é composto por turmas de amigos ou de vizinhos, saudados por palmas e risos seja de alguns espectadores matutinos que se aglomeram nas calçadas, seja (principalmente) de famílias que despertam e, abertas as janelas, entoam com eles algumas das músicas. À tarde, começa a cidade a vibrar com o samba constante de inúmeros Blocos de Sujos, que percorrem espaços muito próximos às arquibancadas. São eles compostos exclusivamente de rapazes, ora vestidos de mulher, ora simplesmente com suas roupas pelo avesso, tocando latas e sacudindo chocalhos. Como o nome indica, trata-se de moçarada de poucas posses, que não podem se inserir nos blocos e cordões e muito menos freqüentar os bailes, nem mesmo os mais modestos, divertindo-se então com o que está ao seu alcance. Tarde da noite, tem lugar os primeiros bailes dos festejos do ano, que se realizarão também no domingo e na $2^{\mathrm{a}}$ feira.

Nos dias seguintes, além dos bailes infantis à tarde, outros terão lugar à noite. Porém, dia e noite, os bandos de Sujos perambulam pelo espaço que é o seu e que, curiosamente, se localiza ao longo das arquibancadas da avenida principal, por onde desfilam, a partir de sábado, os esperados cordões e blocos; as famílias que residem nesta avenida terão seus dias e noites ritmados pelo soar dos sambas entoados por vozes juvenis, marcada a cadência por pandeiros, chocalhos e outros instrumentos improvisados. Durante o dia, num canto ou noutro, Sujos exaustos dormem encostados no dorso das arquibancadas, mas ao acordar, buscam seus grupos e prosseguem na folia. Numa ou noutra rua residencial abastada, há batucadas de jovens sambando sob os olhos de mocinhas risonhas, que cantarolam e arriscam alguns passos de dança; carros e motocicletas deles estão ali parados, e os moços não se movimentam senão alguns passos, pois perdendo-os de vista, arriscam-se a vê-los roubados; a batucada dura até $\mathrm{o}$ início dos bailes de clubes, às 22 ou 23 horas. , quando todos se dirigem para eles. 
Os desfiles de blocos e cordões se realizam nas noites de sábado, domingo e $2^{\mathrm{a}}$ feira, a partir das 19 horas. Os cordões são compostos de jovens do ambos os sexos, dançando em duas fileiras, as alas, entre as quais estão destaques e passistas masculinos e femininos, de roupagens mais rebuscadas, dançando sozinhos; todo o grupo obedece ao apito de um chefe, e a dança é ritmada por um conjunto de percussão. Os blocos, jovens de ambos os sexos com vestimentas iguais, dançam em torno de um conjunto de músicos (sempre com a dominante de percussão) e de um estandarte, cantando e dançando ao som de músicas muito mais vivas e saltitantes do que a dos cordões. Pequenos comerciantes, pequenos funcionários públicos, artesãos, se empenham em organizar estes cortejos; angariam fundos junto às famílias de mais posses da cidade a partir do início do ano,e contam também com pequena contribuição da Municipalidade. Trata-se de um esforço da população de São João del Rei para brincar nos dias de Momo, seguindo o modelo consagrado no país. A simplicidade das fantasias, a pobreza dos ornamentos, a falta de estilo e de elegância, o entoar da música mais para choro do que para samba, indicam o nível modesto de posses da maioria da população e tornam o espetáculo mais do que despretensioso. No entanto, mesmo assim levantam aplausos do público das arquibancadas. Os forasteiros, que ali tinham ido atraídos pela fama dos festejos da cidade, manifestam certa decepção, mas recomendam os autóctones: "Esperem pela $2^{\mathrm{a}}$ feira à noite!"

No dia mencionado, depois de desfilarem os habituais blocos e cordões, eis que uma batucada vivíssima e tonitruante anuncia a chegada de um cortejo diferente. Desemboca na avenida o Cordão Encarnado: mais de uma centena de pessoas fantasiadas de palhaços, de arlequins, de pierrôs, de colombinas, nas cores vermelho e branco, dançando com desembaraço e exaltação, seguidos por bateria numerosa e muito bem fantasiada, cujo ritmo empolgante revela a competência dos executantes. O desfile segue o modelo carioca das Escolas de Samba, com belíssima Comissão de Frente, com lindas alas masculinas, femininas e infantis, com porta-estandarte e mestre-sala dançando com rara elegância o seu pas de deux, com destaques ricamente trajados o cortejo de um mundo "outro" ali se exibe agora...

Efetivamente. Trata-se dos membros das famílias mais ricas e conceituadas que, por "tradição", conservam suas casas em São João del Rei para férias ou para moradia quando aposentados, vindo todos os anos à cidade para brincar o Carnaval. Noutros tempos, seus avós e seus pais, quando ainda ali habitavam, haviam organizado os festejos, formando cordões e blocos ricamente trajados, animando com sua alegria e suas cores a atmosfera habitualmente mortiça da velha urbs. Filhos e netos, morando agora em Belo Horizonte - a capital de Minas Gerais - ou no Rio de Janeiro - a capital do samba - decidem trazer de volta a beleza e o entusiasmo ao berço de seus maiores, animando os Dias Gordos que constituem herança cultural desta cidade tradicional: não querem que nada se perca. Carinho- 
5. O destaque - a palavra significa quem sobressai, é sempre uma pessoa conhecida, de renome, de prestígio, convidada para desfilar em posição que chame a atenção - ou num espaço vazio, ou no alto de um carro alegórico. $\mathrm{O}$ passista, homem ou mulher, distingue-se porque inventa passos extraordinários em seu bailado e vem sempre num espaço livre para poder executá-los sem problemas e ser bem apreciado. samente acolhidos e festejados, se esmeram para que a beleza e a elegância venham desfilar com eles, e, na opinião unânime do povo, constituem o ponto alto da festa carnavalesca.

Os dois extremos da hierarquia sócio-econômica de São João del Rei não concorrem ao concurso carnavalesco patrocinado pela Prefeitura local. A elite é mantida fora porque seria injusto medir o sucesso das agremiações locais com a do Cordão Encarnado, que é imbatível. Os Blocos de Sujos porque sua pobreza e feiúra parecem - como que por definição - afastá-los de qualquer concurso; os variados níveis sócio-econômicos da cidade demonstram assim nem mesmo tomar conhecimento de sua existência...

Em Piracicaba, que das três cidades estudadas é a mais rica, um desaponto: o Carnaval se reduz exclusivamente a bailes nos clubes e a desfiles de escolas de samba, formados por agremiações da cidade e se exibindo no domingo e na $3^{\mathrm{a}}$ feira Gorda; a $2^{\mathrm{a}}$ feira Gorda fica reservada para escolas de samba que vêm em visita nesse dia. Afora essas atividades, a cidade vive a tranqüilidade de um fim de semana prolongado, com o ligeiro corte da $2^{\mathrm{a}}$ feira Gorda, em que a maioria das casas comerciais abrem e em que o funcionalismo público trabalha pela manhã até o meio-dia. Assim, nos Dias Gordos, a cidade se mantém extremamente calma, com exceção da avenida em que foram armadas as arquibancadas para o desfile; nem Blocos de Sujos, nem mascarados solitários ou em grupo, perambulam por suas ruas. A cidade vive longe de qualquer rumor, a não ser nas ruas imediatamente próximas à avenida em que tem lugar o desfile e, tarde da noite, nas imediações dos clubes onde se realizam os bailes. Quem não passar por esses locais, nem perceberá que o Carnaval está ocorrendo. A avenida, bastante longa, fica em fundo de vale e é do começo ao fim ladeada por arquibancadas; só aqueles que adquirem ingressos têm a possibilidade de gozar do espetáculo que as escolas oferecem. E trata-se de um espetáculo brilhante, com poucos carros alegóricos porém com quantidade de participantes em suas fantasias reluzentes; com destaques ricamente trajados; com mestre-sala e porta-bandeira executando impecavelmente o seu minueto ao som de excelentes bateristas de vestimentas coloridas, marcando em compasso de samba os passos dos participantes. Das arquibancadas acompanham cantando os assistentes, batendo palmas quando um detalhe mais belo, um destaque mais cintilante ${ }^{5}$, um passista desenvolto, chama a atenção do público. Há também um júri que distribuirá prêmios para a escola mais rica, para a mais original, para a que venha sambando com maior entusiasmo, júri formado por pessoas competentes.

De onde provém estas escolas de samba? Sua composição é original. Uma ou outra, muito menos brilhante, nasce num bairro da cidade, porém de modo algum entra em competição com as grandes; servem de entretenimento no início do desfile, ou como um intervalo no meio dele. As demais, que constituem o prato de resistência do espetáculo, represen- 
tam as fábricas e as usinas da cidade e de seus arredores: operários e operárias compõem as diversas alas, os passistas, a porta-estandarte e o mestre-sala. Os destaques são filhos e filhas dos grandes usineiros e industriais, e até mesmo uma esposa jovem de um dos maiorais pode vir instalada no alto de um carro alegórico, sambando e cantando. Não raro os próprios patrões abrem o cortejo na Comissão de Frente, envergando smokings coloridos, cartola nas mãos, pedindo passagem ${ }^{6}$.

A competição entre as escolas de samba não é apenas carnavalesca; ela significa também a rivalidade econômica dos grandes patrões, levada ao nível dos operários que constituem com suas mulheres, seus filhos e filhas, os desfilantes. O Carnaval se torna, assim, um momento de demonstração de poder e de riqueza de industriais e usineiros, de donos de prestigiosas fábricas ou de vastas plantações de cana com seus engenhos moderníssimos. Mais ainda, ele é também um instrumento para captar a fidelidade dos operários e dos roceiros, atraídos para seus postos de trabalho e nele mantidos pelo desejo de participar deste desfile, de fazerem brilhar nele suas mulheres e prole. O império e a autoridade dos grandes ficam reforçados pela festa, que também demonstra aos rivais a importância de suas posses; e com verdadeira ingenuidade justificam sua maneira de agir com a mesma afirmação de seus antepassados de fins do séc. XIX ${ }^{7}$ : "Vamo à rua p'ra diverti o povo", o que consideravam um de seus deveres... Em que medida o desfile do Cordão Encarnado, em São João del Rei, conserva esse sentido?

É verdade que seus componentes fazem parte das famílias gradas da cidade, porém a abastança de seus membros não provém exclusivamente de atividades econômicas exercidas nela ou em suas imediações. Os ricos que ali habitam, proprietários e dirigentes das minas dos arredores, são espectadores, não se imiscuem entre os que compõem os cordões. Pequenos comerciantes, pequenos funcionários públicos e suas famílias formam os blocos que desfilam diante das arquibancadas. Quanto aos jovens operários, estes se integram nos Blocos de Sujos que perambulam incansavelmente nas imediações da avenida principal, durante o Reinado de Momo. Seria interessante um estudo mais aprofundado do Carnaval de São João del Rei para verificar se, além dos integrantes do Cordão Encarnado que provém de famílias antigas e ricas da cidade e de seus amigos, outros foliões também nele desfilam e quem são. Não esquecer, porém, que estes grupos do Cordão Encarnado mantem relações e poder político na cidade, na sua região e inclusive no Estado de Minas Gerais, podendo então a conservação do folguedo constituir um lembrete anual ao mando que ainda ali detém ${ }^{8}$.

E a cidade de Tatuí, como se destaca ao lado destas duas outras para merecer também ser apontada como possuindo um Carnaval de certa importância? A cidade apresenta desfile de escolas de samba e blocos, mas como já se observou, não é suficientemente importante para que sejam
6. A Comissão de Frente é um elemento tradicional dos cortejos carnavalescos, desde meados do séc. XIX, quando estes eram organizados pelas grandes fortunas das cidades; era então a cavalo que vinham os maiorais, com suas cartolas na mão, pedindo ao povo que abrisse caminho para eles passarem com os grupos ricamente trajados (ver Pereira De Queiroz, 1992, p. 51-56).

7. Na segunda metade do séc. XIX, havia também enormes desfiles de carnaval nas ruas das maiores cidades brasileiras; eram organizados pelos grandes comerciantes, grandes proprietários rurais, pelos jornais importantes e atraíam uma quantidade de espectadores entusiasmados (Eneida, 1958; Von Simson, 1984; Pereira De Queiroz, 1992).

8. A família do grande político Tancredo Neves é originária de São João del Rei; no ano em que foi feita a análise da festa, 1981, tive ocasião de verificar que toda a família se instalara no seu belo casarão a partir do Sábado Gordo, preparando-se para desfilar no Cordão Encarnado. Eleito presidente da República 
no ano seguinte, no primeiro pleito realizado após uma ditadura militar que durara perto de 20 anos, Tancredo Neves, doente, faleceu antes de tomar posse. No ano seguinte, sua família e alguns políticos pretenderam que ali não seria mais realizada a festa, em homenagem ao morto; encontraram grande resistência da parte dos habitantes e a realização continuou a ser feita.

9. Bumba-meu-boi - uma das "danças dramáticas" realizadas pelas mais variadas regiões do Brasil, com nomes diversos, muito querida pelo povo; é de origem ibérica (Cascudo, 1962, vol. I, p. 140-145).

10. No Rio de Janeiro, as escolas de samba, nascidas nessa cidade, surgiram em 1928, mas só se firmaram como representantes válidas do Carnaval de rua em fins da década de 1930. Porém somente a partir dos anos 50 foram consideradas parte integrante e importante dos festejos de Momo (ver Goldwasser, 1975; Leopoldi, 1978; Rodrigues, 1984; Pereira De Queiroz, 1992). construídas arquibancadas, e somente cordas ao longo da rua principal da cidade separam o leito dela das calçadas, onde ficam os espectadores, valentemente em pé durante bastante tempo. As escolas de samba, pequenas e modestas, são mantidas por vários conjuntos de comerciantes e também por funcionários públicos; os blocos, pequenos grupos de pessoas fantasiadas, aglomeradas em torno de um estandarte, são constituídos de famílias amigas ou de vizinhos. Entre todos estes componentes existe rivalidade, alimentada pelos prêmios outorgados pela municipalidade e pela pequena imprensa local. Mas estes folguedos de Momo tão modestos não explicam porque Tatuí é tida como uma cidade cujo Carnaval vale a pena ser visto.

É que Tatuí se orgulha porque possui algo de inédito em todas as demais cidades brasileiras: o Cordão dos Bichos, que desfila desde 1928. Trata-se de um grupo de figuras variadas em papier-maché - girafas, ursos, elefantes, grandes sapos, grandes borboletas, cavalos, bois, cabeçorras e gigantes - organizado por um modesto comerciante e seus parentes. O Cordão abre o desfile; as investidas dos animais contra o público e a musiquinha de charanga lembram os antigos bumba-meu-boi ${ }^{9}$ tradicionais e são saudadas com palmas, com risos, com fugas e gritos das crianças. Trata-se de uma reação de estima e não de verdadeiro entusiasmo, o qual se desencadeia mais tarde, quando surgem cordões e blocos. Aliás, o Cordão dos Bichos não entra na competição pelos prêmios, é hors concours.

Na verdade, a continuidade do Cordão dos Bichos não é devida ao apreço dos habitantes e sim a uma outra circunstância relativa ao Estado de São Paulo. No início dos anos 60, a Secretaria da Cultura do Estado preocupou-se com o desaparecimento de várias manifestações do folclore paulista e resolveu incrementá-las inclusive com subvenções. O Cordão dos Bichos era então quase que a única manifestação carnavalesca de Tatuí; alguns blocos desfilavam também; mas as escolas de samba só surgiram mais tarde ${ }^{10}$. A partir desse ano, o Cordão dos Bichos teve assegurada a sua sobrevivência. Esta, no entanto, está ameaçada por uma nova circunstância: tempos atrás, muita gente vinha se oferecer para sair no Cordão, envergando uma das fantasias de bichos, cuidadosamente guardadas numa velha garagem, mas desde o aparecimento das escolas de samba e o aumento dos blocos, não há mais quase interessados; para que nenhum dos trajes fique de lado, os organizadores pagam modestas gratificações a gente da roça, que se esmeram mas que não tem a desenvoltura e a graça dos citadinos. O "inventor" do Cordão dos Bichos, que até hoje o dirige, prevê que, se não forem aumentadas as subvenções do governo do Estado e da prefeitura local, o Cordão dos Bichos estará fadado a desaparecer.

Os estudiosos mais conhecidos do carnaval o tem definido como a festa em que é permitido o desencadeamento de uma espécie de loucura coletiva propagando-se por contágio e libertando tendências individuais habitualmente refreadas, que poderiam então ser satisfeitas sem riscos devido ao anonimato trazido pelas fantasias e máscaras; os indivíduos se 
sentiriam à vontade no meio da multidão, na qual todos os seus semelhantes estariam também dando largas às suas extravagâncias e invenções. Loucura coletiva, anonimato na multidão, seriam explicações válidas para os exageros e frenesis carnavalescos. Anulando as normas sociais existentes ou invertendo-as, o Reinado de Momo seria o momento da desordem e da orgia, celebrando a ruptura entre festa e cotidiano.

O sociólogo que primeiro se preocupou em formular uma teoria sobre o Carnaval, Roger Caillois descrevera, em obra publicada em 1939, o Carnaval brasileiro, alegre e descontraído, que tivera a ocasião de assistir no Rio de Janeiro; pôde revê-lo em 1949, e, na segunda edição que então trouxe à luz, confirma suas observações: "durante uma semana inteira, toda a população da cidade e de seus arredores se mistura, canta e dança, se agita muito barulhenta, numa efervescência quase ininterrupta". A interpretação que deu então foi baseada em obras de Durkheim e Mauss, ao analisarem a ruptura entre a fase profana cotidiana e a fase propriamente religiosa, encarando-as como irredutivelmente separadas, de tal modo que os comportamentos dos indivíduos, numa fase, eram inteiramente opostos aos da outra, uma vez que se inverte o embasamento delas, constituído pelas estruturas sociais dos grupos. Roger Caillois acreditou ter presenciado ao vivo esta inversão de estruturas e de ações (Caillois, 1950, p. 9).

Mikhail Bakhtine, em seu estudo famoso sobre Rabelais e o carnaval medieval, pretende que os indivíduos, nesse período, penetram "no reino utópico da universalidade, da liberdade, da igualdade e da abundância" , em que haveria "a abolição de todas as relações hierárquicas" e se instalaria uma outra estrutura social, "na qual todos eram considerados iguais e em que reinava uma forma particular de contatos livres, familiares, entre indivíduos separados na vida normal pelas barreiras intransponíveis constituídas por sua condição, sua fortuna, sua profissão, sua idade, sua situação de família" (Bakhtine, 1970, p. 18-19).

No Brasil, Roberto da Matta interpretou de maneira semelhante a festa de seu país. Na sociedade nacional, em que são reprimidas as tendências habituais e tudo é delimitado por conjuntos de leis, de regulamentos, de etiquetas, o Carnaval opera uma grande ruptura: "no Carnaval (...) a lei é não ter lei" (Da Matta, 1979, p. 84, 94, 108-109). As normas sócioculturais existentes são desobedecidas, a hierarquia de classes desaparece, assim como a dominação do homem em relação à mulher, dos brancos em relação aos negros.

A partir dos anos 70, historiadores franceses formularam outras interpretações do Carnaval, partindo da análise de sua realização e da organização social vigente no momento dele ${ }^{11}$; Jacques Heers, com seu trabalho comparativo sobre a Nave dos Loucos e a festa carnavalesca, teve a ocasião feliz de mostrar este outro caminho para a compreensão do Reinado de Momo (Heers, 1983). A investigação dos festejos seguindo uma abordagem sócio-histórica, analisa a época, procura saber quem eram os
11. Ver Mesnil (1974); Boiteux (1977); Bonnain (1977); Faure (1978) e Le Roy Ladurie (1979). 
foliões, a sua posição na hierarquia do poder local e da própria festa, e também qual a sua colocação na estrutura da mesma. A ligação profunda entre as diversas formas da folia dos Dias Gordos e a estrutura social em que elas se realizam, fazem com que a maneira de colocar o problema tome uma orientação diversa da que vinha tendo até então.

Estas considerações orientaram as pesquisas que efetuei sobre o Carnaval nacional, e parte de seus resultados forma um volume já publicado no Brasil e na França. Nelas pude discernir a diferença existente entre o mito do Carnaval e aquilo que se passa na realidade durante a festa. Desde o passado mais recuado - pois o Carnaval foi trazido ao país com os colonizadores portugueses, no séc. XVI, aqui se desenvolveu e modificou manteve-se relacionado com as aglomerações urbanas, de qualquer tamanho e espécie; "a classe dominante nacional manteve sempre sua preponderância" e a instalação da festa "nunca significou uma reviravolta na ordem sócio-econômica e política existentes". Durante o séc. XIX, em que o antigo festejo colonial se transformara no Carnaval burguês, "a camada superior reinou triunfante sobre os folguedos e os organizou segundo o que julgava melhor". Já no século atual, o Carnaval popular, "trazendo a participação das camadas inferiores à festa, poderia significar uma modificação de camadas sociais" em que subitamente as inferiores tomariam a direção da folia; mas, quando o fazem, é "por delegação dos estratos superiores, e estes, na verdade, permanecem dominantes". Deste modo, verifica-se que no Carnaval brasileiro "a ordem não é subvertida e, durante os quatro dias do Reinado de Momo, o nível superior guarda sua preponderância" (Pereira de Queiroz, 1992, p. 218).

A pesquisa realizada em cidades de menor porte confirma estas reflexões do trabalho anterior; o contrário poderia ocorrer, pois sabe-se que na organização das megalópoles (e o Rio de Janeiro é uma delas) as relações entre os indivíduos passam a ser impessoais, distantes, governadas pela categoria a que se pertence; neste tipo de sociedade, haveria maiores possibilidades de serem conservadas as estruturas sócio-econômicas do cotidiano, impessoais e por categorias, que se conservariam no Carnaval. Já em cidades menores, onde aumentam as possibilidades de um contato pessoal entre os habitantes, desenvolvendo-se com mais freqüência laços diretos, estes últimos mesmos poderiam com mais facilidade diminuir a influência das posições sócio-econômicas no dia-a-dia e apagá-las no Reinado de Momo. Mas nem mesmo em Tatuí, a menor das três cidades, esta ocorrência foi observada; também nela, não se misturaram as camadas sociais, o que se reflete de maneira muito clara na necessidade de pagamento de estipêndio aos componentes do Cordão dos Bichos, gente humilde do campo.

Realmente, nas cidades observadas, o que nelas se encontrou foi uma organização semelhante à que é vista no Rio de Janeiro, com a predominância atual das escolas de samba. Aliás, como foi possível verificar no 
estudo do Carnaval na antiga capital do Brasil, as escolas de samba foram uma modernização de blocos e cordões; segundo o que se viu nas cidades menores, estes tenderiam ainda a aparecer nos desfiles que constituem a festa, porém estão sendo desbancados pela forma mais moderna de organizar os cortejos, que é a da escola de samba. Desse modo, pode-se dizer que, nas cidades pequenas, existe a tendência a copiar aquilo que ocorre nas grandes cidades (Pereira de Queiroz, 1992, p. 185-193); a cópia seria mais ou menos próxima do modelo segundo o porte da aglomeração urbana estudada e a denominação de cordão também tenderia a ser conservada.

A uniformidade de folguedos folclóricos no Brasil, assim como de sua estrutura e organização sociais, desde os tempos recuados do período colonial, causara a admiração de Roger Bastide quando realizou suas investigações, durante os dezesseis anos em que lecionou Sociologia na Universidade de São Paulo. Por isso, considerou as manifestações festivas "pobre em variações locais", apesar da diferença geográfica das diversas regiões, de norte a sul do enorme país (Bastide, 1959, p. 4-5). Por toda a parte, as mesmas danças alegres ou dramáticas, as mesmas manifestações que dir-se-ia copiadas das antigas procissões religiosas portuguesas, nas quais abundavam os mascarados, os grupos dançantes, a música festiva. Não via uma multiplicidade de celebrações diferentes, como ocorre na Europa - e Portugal não é exceção - onde quase se modificam de aldeia a aldeia. Constatou que, tal "monotonia sócio-cultural, notada nas regiões brasileiras", não decorre nem de uma monotonia geográfica, nem de uma monotonia étnica. Geograficamente, as escarpas do extenso litoral de Leste coberto de florestas densas, as chapadas do interior do país que vão descaindo pouco a pouco para Oeste, a região árida do Nordeste com seus cactos, a imensa floresta amazônica se estendendo do Atlântico até as faldas dos Andes peruanos, as planícies do extremo Sul, compõem fisionomias muito diversas aos olhos dos viajantes. Quanto às componentes étnicas, a princípio reuniram três raízes formadas pelos indígenas autóctones, pelos colonizadores portugueses, pelos escravos, vindos da África, e cada qual trouxe uma parte de suas festas para compor um novo acervo cultural; o contingente aborígine misturou-se com o contingente europeu e com o contingente africano, muito mais numa justaposição do que numa mistura, podendo-se então reconhecer, nas festas, o que era parte da herança de cada um dos três acervos. No Carnaval, o cortejo é francamente europeu, porém música e danças são marcadas pela África. Dessa maneira, a monotonia cultural originou-se na implantação, "por toda a parte, das mesmas estruturas de poder, mesmas relações de sociabilidade, mesmos tipos de propriedade e de economia; submetida às mesmas regras a evolução sócio-política seguiu por toda a parte mais ou menos o mesmo curso, as mesmas novidades se implantaram mais ou menos nas mesmas épocas" (Pereira de Queiroz, 1992, p. 202).

A análise feita no atual trabalho permite deslindar um outro aspecto que fôra pouco aflorado no anterior: o das diferenças que podem 
12. Ver também Von Simson (1984); Rodrigues (1984) e Von Simson (1989). ocorrer, embora o esquema geral seja o mesmo. Uma das primeiras observações esclarece que a variação na riqueza e no tamanho das cidades leva a alguma diversidade que se pode salientar. Nas cidades maiores e mais ricas, o modelo do Carnaval carioca é seguido mais de perto do que numa cidade pequena como Tatuí; realmente, o desfile carnavalesco de Piracicaba, embora não chegue ao exagerado porte das escolas de samba do Rio de Janeiro com seus 6000 ou mais figurantes, já apresenta um tamanho e uma riqueza que os diferenciam totalmente dos de São João del Rei e de Tatuí. Como se vê,o desenvolvimento e a abundância de bens de uma cidade separam sua festa daquela organizada nas cidades de menores haveres; porém o modelo permanece. Uma diferença vai ser encontrada, sim, nestas últimas, sob a forma de variedade (a maior quantidade de folguedos em São João del Rei) ou de originalidade (o aparecimento do Cordão dos Bichos em Tatuí). Em que condições surgiram estas manifestações diversas? Somente um estudo monográfico de cada cidade permitiria verificar.

Mikhail Bakhtine, analisando o Carnaval medieval, afirmou que a festa "ignora qualquer distinção entre atores e espectadores. Ignora também o palco, mesmo quando embrionário... Os espectadores não assistem o Carnaval, todos eles o vivem, porque, por sua qualidade mesma, o Carnaval é feito para o conjunto do povo. Durante todo o período carnavalesco, ninguém conhece outra vida senão a do Carnaval. Impossível escapar, o Carnaval não tem fronteiras espaciais. Enquanto dura a festa, só se pode viver conforme suas leis, isto é, conforme as leis da liberdade" (Bakhtine, 1970, p. 15). Estas afirmações, que muitos autores aplicaram às festas carnavalescas atuais, não é adequado aos exemplos aqui apresentados e nem, estou plenamente convicta, ao Carnaval brasileiro tal qual o tenho estudado através do tempo (Pereira de Queiroz, 1992) ${ }^{12}$.

Mesmo em se tratando de uma cidade pequena como Tatuí, em que se poderia supor que, conhecendo-se com mais facilidade uns aos outros, desaparecessem entre os habitantes do local as diferenças sócio-econômicas e outras durante a festa, o contrário foi observado. Admite-se que de certo modo a festa é vivida ao mesmo tempo por espectadores e atores; porém cada uma das categorias tem a sua maneira de viver a festa. Tanto é assim que o folião é o ator; na linguagem corrente, os espectadores não são denominados foliões, qualificação específica daqueles que saem pelas ruas fantasiados, seja nos cordões, nos blocos, nas escolas de samba. Existe, sim, a delimitação entre o palco e a platéia, em todos os cortejos; o palco é o leito das ruas, a platéia se comprime nas calçadas numa cidade menor como Tatuí, porém nas maiores e mais ricas ela é efetivamente construída sob a forma de arquibancadas e, como em qualquer teatro, paga-se um preço para destas usufruir. No caso de Tatuí, poder-se-ia pensar que os espectadores não são mais diferenciados economicamente; mas existe pelo menos um embrião de discriminação quando as famílias de maiores posses colocam bancos e cadeiras à beira da calçada, onde ficam sentados 
empregados ou empregadas domésticas, ou até mesmo moleques que recebem uma gorjeta para ali literalmente guardarem os lugares dos patrões, que somente na hora de iniciar o desfile virão ali sentar e gozar comodamente do espetáculo, sem o empurra-empurra da multidão. Quanto aos servidores, parte integrante do carnaval, são inconfundíveis...

Em que medida será possível aplicar a todas as cidades do Brasil estas observações? Acredito que a grande maioria delas não se diferenciará do que aqui se analisou ${ }^{13}$. Assim sendo, a loucura coletiva, o anonimato da multidão e outros fatores causais encontrados para explicar a continuidade do Carnaval não justificam a existência desta festa nem tornam inteligível o seu significado. Tal constatação justifica que a análise siga uma outra direção; não mais a orientada pela emoção, como tem sido realizado até agora, e sim tomando a perspectiva apontada pela Sociologia.

A perspectiva sociológica se evidencia pela busca de diferenças, de distinções, de limites traçados entre sociedades, entre grupos no interior da sociedade, entre indivíduos no interior ao grupo. Adotada esta posição diante do Carnaval nas três cidades escolhidas, a análise revelou, primeiramente, que em todas elas as distinções sócio-econômicas habituais não se apagavam durante a festa, porém persistiam como durante o cotidiano, constituindo a estrutura de base dos grupos. No entanto, era possível distinguir uma outra ordem, além das costumeiras, que existia exclusivamente entre os participantes da festa. Portanto, a festa se expressava primeiramente por criar, no interior da ordenação habitual e sem destruir a esta, uma outra ordem que lhe é peculiar. Esta se instala exclusivamente no terreno específico da festa, representado pelos locais em que se realizam os bailes e pelas ruas onde passam os desfiles.

A ordem carnavalesca se caracteriza pela distinção entre atores, espectadores e servidores, os quais agem de maneira diferente durante a festa. No entanto, a ordem não-festiva persiste durante a sua realização. Quando organizados em teatros, os bailes têm os seus atores e os seus espectadores de maneira muito visível - os primeiros estão nas frisas e camarotes, e em geral são constituídos por pessoas gradas (prefeitos, vereadores, gente das famílias ricas), que raramente descem à platéia, de onde foram retiradas as poltronas e onde, reunida ao palco, os foliões dançam. Mas mesmo em salões de clube, a distinção permanece; em torno do salão, mesas e cadeiras acolhem os espectadores, enquanto no centro saracoteiam os atores. A terceira fração dos componentes, os servidores, são facilmente encontrados e, além de uma função muito diferente dos outros dois segmentos pois estão ali a trabalho, ninguém esquece que pertencem sempre a uma camada social inferior. Finalmente, o clube permitindo a entrada a seus sócios e cobrandoa dos que não o são, traça um limite que é sócio-econômico entre os que ali vão se divertir e os demais; a classificação dos clubes entre os de camada superior, média e inferior, a não-abertura dos bailes a todos os habitantes da cidade mostram que a folia não aboliu as distinções sociais.
13. O Carnaval da cidade de Salvador, capital da Bahia, merece ser estudado devido a ter evoluído de maneira diversa, a partir de um início semelhante ao do Carnaval de todo o Brasil. No entanto, ali também são conservados os sinais específicos das classes sociais durante a festa e a fantasia dos integrantes de um bloco é o sinal que imediatamente o situa no grupo a que pertence e na camada social que é a sua; pois cada bloco se enquadra numa camada social, ou então sócio-profissional (Pereira De Queiroz, 1978; Roxo Nobre, 1978 e Ortiz, 1980). 
A separação entre atores e espectadores é discernível com muito maior clareza nos desfiles carnavalescos. Ali também os servidores são plenamente visíveis, tanto mais que o lugar que ocupam fica à beira daquele destinado a atores e espectadores; não se misturam com as duas outras categorias, há um local do espaço que lhes é atribuído especificamente; também conservam inteiramente sua categoria sócio-econômica, que não é apagada pela festa. São igualmente designados espaços específicos para atores e espectadores. No que diz respeito aos espectadores, o lugar que ocupam indica imediatamente a que seção sócio-econômica pertencem. No caso dos atores, também é visível esta distinção; em São João del Rei e em Tatuí, cada escola de samba e cada bloco corresponde a famílias ou a grupos de amigos, ou a grupos de vizinhança cuja situação social é conhecida e que trazem inscrita em sua indumentária o nível econômico a que pertencem. Em Piracicaba, a complexidade é maior porque no interior de cada escola de samba são encontrados todos os níveis sócio-econômicos de uma empresa; mas, se cada uma não provém de uma camada social distinta, é porque cada uma representa uma das grandes fortunas locais e é no seu interior que vão ser encontradas distinções de classe, separando patrões e família, pelas roupagens e pela posição no cortejo,daquela em que estão funcionários e operários, embora partilhando da mesma escola de samba.

Assim, nem mesmo os atores participam da festa perdidos numa grande coletividade homogênea que os torne anônimos; estão reunidos em grupos perfeitamente diferenciados, cujas fantasias ou trajes , cujas danças, cujos cantos não preservam identidades individuais e sim uma identidade ou grupal, ou de camada social. Fantasias e roupagens, a batida dos $\operatorname{surdos}^{14}$, o samba específico de cada escola de samba ou de cada bloco demonstram justamente a vontade de não se perder na multidão, ao contrário do que afirmam alguns dos estudiosos do Carnaval nacional e do Carnaval em geral. A constituição dos grupos é uma forte reação contra o anonimato individual e coletivo. Os espectadores, por sua vez, conservam seus agrupamentos da vida cotidiana; não se vai assistir sozinho o desfile de escolas de samba ou de blocos, e sim nos mesmos grupos da vida diuturna: a família, a vizinhança, os amigos.

Desta maneira, toda a estrutura social do cotidiano está presente na festa carnavalesca, cujos foliões e espectadores não são formados por uma pretensa multidão anônima. Espectadores e foliões, em seus delírios de entusiasmo, podem chegar a um estado quase alucinado de exaltação, porém não perdem de vista seu grupo, que lhe dá nesse momento o mesmo firme apoio que dele se espera no dia a dia. Poder-se-á, então, denominar multidão o grande grupo que se reúne para os festejos de Momo, uma vez

14. Surdo - grandes tambores africanos que constituem a base das músicas das escolas de samba. que o termo designa um conjunto não estruturado de pessoas que se encontram unidas por um liame ocasional e instável, num mesmo momento e num mesmo lugar, apagadas todas as diferenciações do cotidiano? Não, pois não foi encontrado no Carnaval brasileiro. 
A ordem carnavalesca, no Brasil, não contraria a ordem habitual da sociedade existente. Também não oferece embasamento para a construção de uma coletividade totalmente outra, que seria rebelde, igualitária, fraterna, além de fugitiva e ilusória. A ordem carnavalesca define posições e papéis sociais inteiramente dentro das hierarquias sócio-econômicas existentes, de acordo com as relações sociais básicas. Nem revolucionária, nem destrutiva, a ordem carnavalesca é mimética da ordem de todos os dias, sobre a qual se apóia.

Talvez a análise do Carnaval em perspectiva sociológica ofereça o melhor apoio para se definir com clareza a distinção entre uma abordagem como estas e a abordagem psicológica. Porque a emoção carnavalesca existe, e as emoções constituem indubitavelmente parte da realidade psico-sociológica. A emoção carnavalesca se apodera dos indivíduos (daqueles que são propensos, porque existem os que são imunes...), comandaos, impele-os a participar de diversas maneiras, olhando, dançando, cantando, fazendo despesas loucas com uma indumentária que usará, às vezes, apenas algumas horas. E no espaço carnavalesco, sob o império da emoção, todos se sentem fraternos e iguais. No entanto, mesmo assim, estão enquadrados pelos limites das estruturas sócio-econômicas existentes, e, mesmo quando ultrapassam os limites destas, não perdem a noção de sua existência. Nem mesmo durante o Carnaval se opera a proclamada libertação.

Uma vez que as estruturas sociais permanecem presentes, seria interessante um estudo que tentasse unir a elas a perspectiva sócio-psicológica, buscando ver se as emoções despertadas, suas formas, conteúdo, intensidade, seriam semelhantes, reunindo num só conjunto as camadas sociais, ou se manifestariam diversas, e quais as suas formas, segundo as camadas sociais. Pesquisa em que seriam indagados os indivíduos, conservando-se sempre como pano de fundo o sexo, as categorias sócio-econômicas e outros possíveis fatores de diferenciação.

Recebido para publicação em março/1995

QUEIROZ, Maria Isaura Pereira de. The Carnival order. Tempo Social; Rev. Sociol. USP, S. Paulo, 6(1-2): 27-45, 1994 (editado em jun. 1995).

ABSTRACT: The author studies the Carnival shows in the cities Tatuí, Piracicaba and São João Del Rei. Based on the observation of the ways by which Carnival is celebrated at the parties and in the streets of these cities, she questions usual interpretations that conceive Carnaval as a situation in

UNITERIMS:

Carnival, order, social structure, everyday life. 
which all the norms citizens usually adapt themselves to seem to be abolished. On the contrary, the research shows that the daily social structure lasts during this feast, a fact that can be realized by noticing the separation of the coarse jesters and spectators, the presence of different social groups at the parties and in the various Carnival "blocs" [groups of people who dance together in the festive procession]. These facts point out that the persons' socio-economic origins are carried on during the Carnival days.

\section{REFERÊNCIASBIBLIOGRÁFICAS}

BAKHTINE, Mikhail. (1970) L'oeuvre de François Rabelais et la culture populaire au moyen âge et sous la renaissance. Paris, Gallimard.

Bastide, Roger. (1959) Sociologia do folclore brasileiro. São Paulo, Ed. Anhembi.

Borteux, M. (1977) Formes de la fête. Annales, économies, sociétés, civilisations. Paris, An XXXII, $\mathrm{n}^{\circ}$ 2, mars-avril.

BonnAIn, R. \& MoERdyK, D. (1977) À propos du charivari: discours bourgeois et coutumes populaires. Annales, économies, sociétés, civilisations. Paris, An. XXXII, $\mathrm{n}^{\circ} 2$, mars-avril.

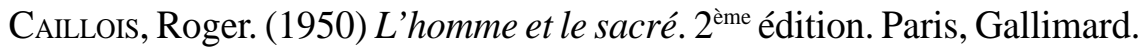

CÂmara Cascudo, Luiz da. (1962) Dicionário do folclore brasileiro. $2^{\mathrm{a}}$ ed. revista e aumentada, 2 vols. Rio de Janeiro, Instituto Nacional do Livro/Ministério da Educação e Cultura.

Da MatTA, Roberto. (1979) Carnavais, malandros e heróis. Rio de Janeiro, Zahar Ed.

EnEIDA. (1958) História do carnaval carioca. Rio de Janeiro, Civilização Brasileira Ed.

FAUre, Alain. (1978) Paris, carême prenant: du carnaval à Paris au XIX siècle (1880-1914). Paris, Librairie Hachette Ed.

Goldwasser, Maria Julia. (1975) O palácio do samba (estudo antropológico da escola de samba estação primeira de mangueira). Rio de Janeiro, Zahar Ed.

HeErs, Jacques. (1983) Fêtes des fous et carnavals. Paris, Fayard Ed.

Le Roy Ladurie, Emmanuel. (1979) Le carnaval de romans. Paris, Gallimard.

Leopoldi, José Savio. (1978) Escola de samba, ritual e sociedade. Petrópolis, Ed. Vozes.

MesnIL, Marianne. (1974) Le lieu et le temps de la fête carnavalesque - trois essais sur la fête du folklore a l'ethno-sémiotique. Cahiers d'études de sociologie culturelle. Bruxelles, Ed. de l'Université de Bruxelles.

OrTIz, Renato. (1980) A consciência fragmentada. Rio de Janeiro, Paz e Terra. 

(editado em jun. 1995).

Pereira De Queiroz, Maria Isaura. (1978) Evolution du carnaval latinoaméricain. Diogène. Paris, nº 104, octobre-decembre. . (1992) Carnaval brasileiro: o vivido e o mito. São Paulo, Ed. Brasiliense. Em francês: Carnaval brésilien: le vécu et le mythe. Paris, Gallimard.

Rodrigues, Ana Maria. (1984) Samba negro, espoliação branca. São Paulo, Hucitec.

Roxo Nobre, Maria Tereza. (1978) Meandros da participação: formas de compartilhar o espaço (ensaio sobre o carnaval baiano). Ciência e cultura. Revista da Sociedade Brasileira para o Progresso da Ciência. São Paulo, Ano 30, nº 5.

Von Simson, Olga Rodrigues de Moraes. (1984) A burguesia se diverte no reinado de momo (60 anos de evolução do carnaval na cidade de São Paulo). São Paulo, 283 p. Tese de Mestrado. FFLCH, Universidade de São Paulo.

. (1989) Brancos e negros no carnaval popular paulistano. São Paulo, 246 p. Tese de Doutorado, FFLCH, Universidade de São Paulo. 
